\title{
Isolation and structural elucidation of glucoside congeners of platencin from Streptomyces platensis SB12600
}

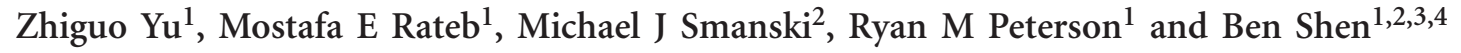 \\ The Journal of Antibiotics (2013) 66, 291-294; doi:10.1038/ja.2013.1; published online 30 January 2013
}

Keywords: antibacterial; antidiabetes; fatty acid synthase inhibitor; glucoside; pathway regulation; platencin; platensimycin

Platensimycin (PTM, 1) $)^{1,2}$ and platencin (PTN, 2) $)^{3,4}$ are recently discovered natural products, which are potent and selective inhibitors of bacterial and mammalian fatty acid synthases (Figure 1a). They have emerged as promising drug leads for both antibacterial and antidiabetic therapies. ${ }^{1-5}$ Although the efficacy of PTM and PTN has been demonstrated in mouse models, they suffer from poor pharmacokinetic properties, mainly a high rate of clearance, thereby requiring continuous infusion to ensure adequate exposure, a delivery method that is not desirable to most patients. ${ }^{6,7}$ Consequently, significant effort has been undertaken to prepare PTM and PTN analogues by organic synthesis, ${ }^{8,9}$ and to isolate PTM and PTN congeners by fermentation optimization. ${ }^{10-21}$ Although these analogues have helped define the structure-activity relationship of PTM and PTN, none of them however can be argued to have significantly improved therapeutic properties.

PTM and PTN were originally isolated from Streptomyces platensis MA7327 and MA7339, respectively. ${ }^{1-4}$ We subsequently cloned and sequenced the gene clusters encoding PTM and PTN biosynthesis from both S. platensis MA7327 and MA7339, unveiling MA7327 as a PTM and PTN dual producer. ${ }^{18,20}$ Inactivation of $p t m R 1$ and $p t n R 1$, which encode a GntR-like transcriptional regulator within the PTM and PTN clusters, ${ }^{18,20}$ in S. platensis MA7327 and MA7339 afforded mutant recombinant strains that dramatically overproduce PTM $^{18}$ and PTN. ${ }^{19}$ Although PTN was produced in very low titre in the wildtype S. platensis MA7339 strain, ${ }^{3,4} 17$ congeners were isolated upon medium optimization and large-scale fermentation. ${ }^{14,16,17}$ From the $\triangle p t n R 1$ mutant strain of S. platensis SB12600 that significantly overproduces PTN, nine additional congeners were isolated, four of which were also isolated from the wild-type strains, albeit at significantly lower yield. ${ }^{19}$ Finally, expression of the ptn cluster from S. platensis MA7339 in the heterologous host Streptomyces lividans K4-114 afforded the production and isolation of six additional PTN congeners. ${ }^{21}$ The 29 PTN congeners isolated to date (summarized in Supplementary Figure S1) could be divided structurally into three subclasses-(i) biosynthetic intermediates, (ii) shunt metabolites en route to PTN and (iii) hydroxylated or glucosylated congeners, most likely resulted from adventitious P-450 enzymes or glucosyltransferases, respectively.

Inspired by our early findings that the PTN-overproducing $\triangle p t n R 1$ mutant strain SB12600 provided an excellent opportunity to isolate PTN congeners that would be produced in titres too low to be detected in the wild-type strain, ${ }^{19}$ we have now subjected S. platensis SB12600 to large-scale fermentation to isolate the minor congeners. Crude extract made from approximately 151 of SB12600 fermentation was subjected to multiple steps of $\mathrm{SiO}_{2}, \mathrm{C}-18$ and Sephadex LH-20 (Sigma-Aldrich, St Louis, MO, USA) chromatography, affording four new PTN congeners, $3(11.8 \mathrm{mg}), 4(10.2 \mathrm{mg}), 5(3.6 \mathrm{mg})$ and $\mathbf{6}$ (4.1 mg; Supplementary Information). Structural elucidation of 3-6 as glucoside congeners of PTN (Figure 1b) was based mainly on HRESI-MS and ${ }^{1} \mathrm{H}$ and ${ }^{13} \mathrm{C}$ NMR spectroscopic analyses, as well as comparison with previously reported glucoside congeners of PTM (7 and $\mathbf{8})^{15}$ and of PTN (9 and 10) $)^{19}$ (Figure 1c).

HR-ESI-MS analysis of 3 yielded $[\mathrm{M}+\mathrm{H}]^{+}$and $[\mathrm{M}+\mathrm{Na}]^{+}$ions at $\mathrm{m} / \mathrm{z} 588.2439$ and $\mathrm{m} / \mathrm{z} 610.2259$, respectively, predicting a molecular formula of $\mathrm{C}_{30} \mathrm{H}_{37} \mathrm{NO}_{11}$ (calculated $[\mathrm{M}+\mathrm{H}]^{+}$and $[\mathrm{M}+$ $\mathrm{Na}]^{+}$ions at $\mathrm{m} / z 588.2445$ and $\mathrm{m} / \mathrm{z} 610.2265$, respectively). The ${ }^{13} \mathrm{C}$ NMR data of 3 (Table 1) was very similar to those of $2,{ }^{4,19}$ with the exception of an extra six resonances, which indicated a hexose moiety. The structure of the PTN aglycone moiety was further confirmed by key COSY and HMBC correlations (Figure 1d). The hexose moiety was established by a 1D-TOCSY experiment, verified to be a glucoside by gHSQC, gHMBC and TOCSY correlations, and further confirmed to be a glucoside by comparison with previously reported NMR data for the PTM glucosides $(7 \text { and } 8)^{15}$ and the PTN glucosides

${ }^{1}$ Department of Chemistry, The Scripps Research Institute, Jupiter, FL, USA; ${ }^{2}$ Microbiology Doctoral Training Program, University of Wisconsin-Madison, Madison, WI, USA; ${ }^{3}$ Department of Molecular Therapeutics, The Scripps Research Institute, Jupiter, FL, USA and ${ }^{4}$ Natural Products Library Initiative, The Scripps Research Institute, The Scripps Research Institute, Jupiter, FL, USA

Correspondence: Professor B Shen, Department of Chemistry, The Scripps Research Institute, 130 Scripps Way, \# 3A1, Jupiter, FL 33458, USA.

E-mail: shenb@scripps.edu

Received 5 December 2012; revised 17 December 2012; accepted 26 December 2012; published online 30 January 2013 
<smiles></smiles>

Platensimycin (1)

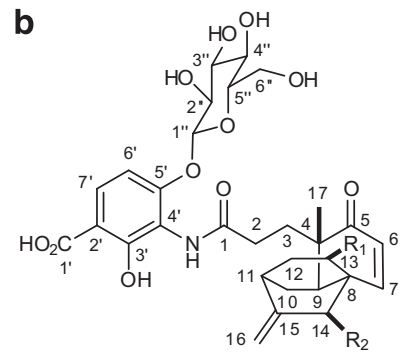

Platencin A12 $\left(3, R_{1}=R_{2}=H\right)$ Platencin A14 (5, $\left.\mathrm{R}_{1}=\mathrm{OH}, \mathrm{R}_{2}=\mathrm{H}\right)$ Platencin A15 $\left(6, \mathrm{R}_{1}=\mathrm{H}, \mathrm{R}_{2}=\mathrm{OH}\right)$

C

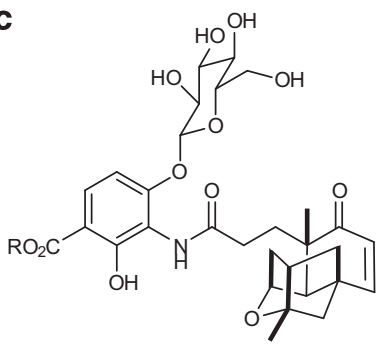

Platensimycin B4 $(7, \mathrm{R}=\mathrm{H})$ Platensimycin B4 ester $\left(\mathbf{8}, \mathrm{R}=\mathrm{CH}_{3}\right)$<smiles>C=C1CC2C=CC(=O)C(C)(C2)C1CCC(=O)Nc1c(O)ccc(C(=O)O)c1O</smiles>

Platencin (2)<smiles>C=C1CC2CCC(=O)C(C)(CCCC(=O)Nc3c(OC4OC(CO)C(O)C(O)C4CO)ccc(C(=O)O)c3O)C1C2</smiles>

Platencin A13 (4)

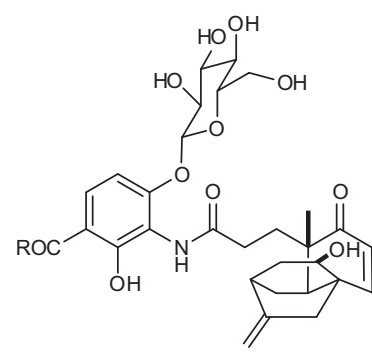

Platencin A9 $\left(\mathbf{9}, \mathrm{R}=\mathrm{SCH}_{3}\right)$ Platencin A10 $\left(10, \mathrm{R}=\mathrm{OCH}_{3}\right)$

\section{d}
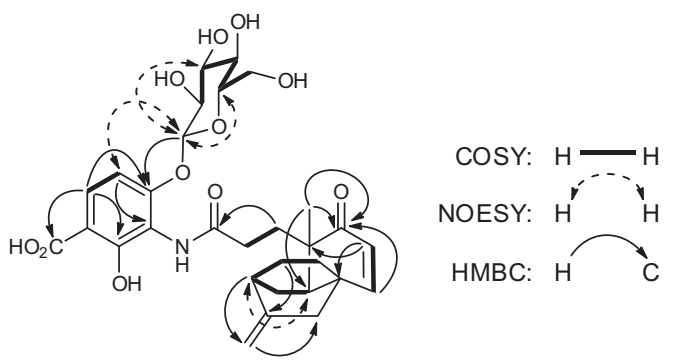

Platencin A12 (3)

Figure 1 Structures of platensimycin (1), platencin (2) and their glucosides (3-10) isolated from wild-type and engineered S. platensis strains. (a) Platensimycin (1) from wild-type S. platensis MA73272 2 and platencin (2) from wild-type S. platensis MA7339. ${ }^{4}$ (b) Platencin A12 (3), A13 (4), A14 (5) and A15 (6) from engineered $S$. platensis SB12600 reported in the current study. (c) Platensimycin B4 (7) and its methyl ester (8) from wildtype S. platensis MA7327,15 and platencin $A 9$ (9) and $A 10$ (10) from engineered S. platensis SB12600. ${ }^{19}$ (d) Key COSY, NOESY and HMBC correlations supporting the structures of 3-6 as exemplified by $\mathbf{3}$.

(9 and 10). ${ }^{19}$ The glucosidic linkage was established at position C-5 by the gHMBC correlation of the anomeric proton $\mathrm{H}^{-1} 1^{\prime \prime}\left(\delta_{\mathrm{H}} 5.71\right)$ to C-5 $5^{\prime}\left(\delta_{\mathrm{C}}\right.$ 158.7). This was further supported by the NOESY correlations between $\mathrm{H}-6^{\prime}\left(\delta_{\mathrm{H}}\right.$ 7.19) and $\mathrm{H}-1^{\prime \prime}\left(\delta_{\mathrm{H}}\right.$ 5.71), which also showed correlations with $\mathrm{H}-3^{\prime \prime}\left(\delta_{\mathrm{H}} 4.36\right)$ and $\mathrm{H}-5^{\prime \prime}\left(\delta_{\mathrm{H}} 4.15\right)$, confirming the $\beta$-D-glucoside configuration (Figure 1d). On the basis of these data, 3 was assigned as platencin A12, a platencin- $5^{\prime}-\beta$-Dglucoside (Figure 1b).
The molecular formula of 4 was deducted as $\mathrm{C}_{30} \mathrm{H}_{39} \mathrm{NO}_{11}$ based on the HR-ESI-MS spectrum that gave $[\mathrm{M}+\mathrm{H}]^{+}$and $[\mathrm{M}+\mathrm{Na}]^{+}$ions at $m / z 590.2596$ and $m / z 612.2416$ (calculated $[\mathrm{M}+\mathrm{H}]^{+}$and $[\mathrm{M}+$ $\mathrm{Na}]^{+}$ions at $m / z 590.2602$ and $\left.m / z 612.2421\right)$, respectively. Comparison of the ${ }^{1} \mathrm{H}$ and ${ }^{13} \mathrm{C}$ data (Table 1 ) of $\mathbf{3}$ and $\mathbf{4}$ indicated a close identity between the two compounds, with the double bond of the enone moiety reduced in 4 . The latter was supported by the 2 mass unit difference between $\mathbf{3}$ and $\mathbf{4}$, and further confirmed by the disappearance of olefinic moiety in $3\left(\mathrm{H}-6 / \mathrm{H}-7, \delta_{\mathrm{H}} 5.90 / \delta_{\mathrm{H}} 6.33\right.$ and C-6/C-7, $\delta_{\mathrm{C}} 126.7 / \delta_{\mathrm{C}} 154.9$ ), with the concomitant appearance of a $-\mathrm{CH}_{2}-\mathrm{CH}_{2}-$ moiety $\left(\mathrm{H}_{2}-6 / \mathrm{H}_{2}-7, \delta_{\mathrm{H}} 1.91,1.04 / \delta_{\mathrm{H}} 1.40,1.34\right.$ and $\left.\mathrm{C}-6 / \mathrm{C}-7, \delta_{\mathrm{C}} 28.4 / \delta_{\mathrm{C}} 35.4\right)$ in 4 , as well as the gHMBC correlations of $\mathrm{H}_{2}-6\left(\delta_{\mathrm{H}} 1.91,1.04\right)$ to $\mathrm{C}-8\left(\delta_{\mathrm{C}} 32.2\right)$ and $\mathrm{H}_{2}-7\left(\delta_{\mathrm{H}} 1.40,1.34\right)$ to $\mathrm{C}-5$ $\left(\delta_{\mathrm{C}} 215.7\right)$ in $4 .{ }^{1} \mathrm{H}$ and ${ }^{13} \mathrm{C}$ NMR data also confirmed the identity of the sugar moiety to that of $\mathbf{3}$ (Table 1 ), and thus $\mathbf{4}$ was assigned as platencin A13, a 6,7-dihydroplatencin- $5^{\prime}-\beta$-D-glucoside (Figure 1b).

The molecular formula $\mathrm{C}_{30} \mathrm{H}_{37} \mathrm{NO}_{12}$ for 5 was established on the basis of HR-ESI-MS analysis that afforded $[\mathrm{M}+\mathrm{H}]^{+}$and $[\mathrm{M}+$ $\mathrm{Na}]^{+}$ions at $m / z 604.2392$ and $m / z 626.2209$ (calculated $[\mathrm{M}+\mathrm{H}]^{+}$ and $[\mathrm{M}+\mathrm{Na}]^{+}$ions at $m / z 604.2395$ and $\left.m / z 626.2214\right)$, respectively. Careful comparison of the ${ }^{1} \mathrm{H}$ and ${ }^{13} \mathrm{C}$ NMR data with previously reported PTN analogues ${ }^{14,16,17,19}$ revealed that the aglycone moiety is identical to that of platencin A1, ${ }^{14,19}$ which is also supported by the 16 mass unit difference from 3. Hydroxylation at C-13 was further confirmed by the gCOSY correlations of $\mathrm{H}-13\left(\delta_{\mathrm{H}} 4.62\right)$ to $\mathrm{H}_{2}-12$ $\left(\delta_{\mathrm{H}} 1.36,1.24\right)$, and NOESY correlation between $\mathrm{H}-13\left(\delta_{\mathrm{H}} 4.62\right)$ and $\mathrm{H}_{3}-17\left(\delta_{\mathrm{H}} 1.05\right)$ verified the configuration of the hydroxyl group at $\mathrm{C}-13 .{ }^{1} \mathrm{H}$ and ${ }^{13} \mathrm{C}$ NMR data also confirmed the identity of the sugar moiety to that of 3 and 4 (Table 1), and hence, 5 was similarly assigned as platencin A14, a platencin A1-5'- $\beta$-D-glucoside.

HR-ESI-MS analysis of 6 provided $[\mathrm{M}+\mathrm{H}]^{+}$and $[\mathrm{M}+\mathrm{Na}]^{+}$ ions at $\mathrm{m} / z 604.2393$ and $\mathrm{m} / z$ 626.2211, respectively, indicating a molecular formula of $\mathrm{C}_{30} \mathrm{H}_{37} \mathrm{NO}_{12}$ (calculated $\left.\mathrm{M}+\mathrm{H}\right]^{+}$and $[\mathrm{M}+$ $\mathrm{Na}]^{+}$ions at $\mathrm{m} / z 604.2395$ and $\mathrm{m} / z$ 626.2214, respectively), which had the same molecular formula as 5 . Careful analysis of the ${ }^{1} \mathrm{H}$ and ${ }^{13} \mathrm{C}$ NMR data (Table 1) revealed that 6 was a regioisomer of 5 . Hydroxylation at C-14 was confirmed by the gHMBC correlations of $\mathrm{H}_{2}-16\left(\delta_{\mathrm{H}} 5.27,5.09\right)$ to $\mathrm{C}-14\left(\delta_{\mathrm{C}} 76.2\right)$, and NOESY correlation between $\mathrm{H}-14\left(\delta_{\mathrm{H}} 3.99\right)$ and $\mathrm{H}-9\left(\delta_{\mathrm{H}} 1.93\right)$ established the configuration of the hydroxyl group at $\mathrm{C}-14$, affording the PTN aglycone that is identical to platencin A3. ${ }^{17,18}$ Finally, ${ }^{1} \mathrm{H}$ and ${ }^{13} \mathrm{C}$ NMR data of $\mathbf{6}$ similarly indicated the same hexose moiety as $\mathbf{3 - 5}$, and this allowed the final assignment of 6 as platencin A15, a platencin A3- $5^{\prime}-\beta$-Dglucoside (Figure 1b).

PTM and PTN congeners isolated to date have helped define the structure-activity relationship of the PTM and PTN scaffolds as promising drug leads for both antibacterial and antidiabetic therapies. $6,7,10-19$ The current work demonstrated once again the power and utility of engineering overproducers by manipulating pathway regulation to isolate natural product congeners that would be produced in titres too low to be detected in the wild-type strains. ${ }^{22}$ Glucosides of both PTM (7 and 8$)^{15}$ and PTN $(\mathbf{9} \text { and } \mathbf{1 0})^{19}$ have been isolated previously (Figure 1c). Glucosylation of the C- $5^{\prime}$ hydroxyl group of PTM and PTN completely abolished their FabF/H inhibitory activity in vitro and antibacterial activity in vivo. ${ }^{15,19}$ This is consistent with the importance of the $\mathrm{C}-5^{\prime}$ hydroxyl group in mediating hydrogen bonding to the $\mathrm{FabF} / \mathrm{H}$ active sites as observed in the PTM- and PTN-bound X-ray structures. ${ }^{1,3,10-19}$ The newly isolated four PTN glucosides (3-6) also showed no antibacterial activity as 7-10 reported previously, ${ }^{15,19}$ further supporting the emerging structure-activity relationship that the C-5' hydroxyl group is critical 
Table 1 Summary of ${ }^{1} \mathrm{H}(700 \mathrm{MHz})$ and ${ }^{13} \mathrm{C}(175 \mathrm{MHz})$ NMR Data for platencin A12-A15 (3-6) in $d_{\sigma}$-pyridine ${ }^{\mathrm{a}}$

\begin{tabular}{|c|c|c|c|c|c|c|c|c|}
\hline \multirow[b]{2}{*}{ Position } & \multicolumn{2}{|c|}{ Platencin A12 (3) } & \multicolumn{2}{|c|}{ Platencin A13 (4) } & \multicolumn{2}{|c|}{ Platencin A14 (5) } & \multicolumn{2}{|c|}{ Platencin A15 (6) } \\
\hline & $\delta_{C}$ & $\delta_{H}(m u l t, J$ in $H z)$ & $\delta_{C}$ & $\delta_{H}(m u l t, J$ in $H z)$ & $\delta_{C}$ & $\delta_{H}(m u l t, J$ in $H z)$ & $\delta_{C}$ & $\delta_{H}(m u l t, J$ in $H z)$ \\
\hline 1 & $173.9, \mathrm{C}$ & & $173.9, \mathrm{C}$ & & $173.8, \mathrm{C}$ & & $173.9, \mathrm{C}$ & \\
\hline 2 & $32.7, \mathrm{CH}_{2}$ & $\begin{array}{l}2.76, \mathrm{t}(11.0) \\
2.57, \mathrm{~m}\end{array}$ & $32.7, \mathrm{CH}_{2}$ & $\begin{array}{c}2.75, \mathrm{t}(11.1) \\
2.63, \mathrm{~m}\end{array}$ & $32.8, \mathrm{CH}_{2}$ & $\begin{array}{l}2.77, \mathrm{t}(11.6) \\
2.59, \mathrm{~m}\end{array}$ & $32.8, \mathrm{CH}_{2}$ & $\begin{array}{l}2.78, \mathrm{~m} \\
2.58, \mathrm{~m}\end{array}$ \\
\hline 3 & $32.2, \mathrm{CH}_{2}$ & $\begin{array}{c}2.60, \mathrm{~m} \\
2.06, \mathrm{t}(10.8)\end{array}$ & $33.3, \mathrm{CH}_{2}$ & $\begin{array}{l}2.36, \mathrm{~m} \\
2.00, \mathrm{~m}\end{array}$ & $32.3, \mathrm{CH}_{2}$ & $\begin{array}{l}2.62, \mathrm{~m} \\
2.04, \mathrm{~m}\end{array}$ & $32.3, \mathrm{CH}_{2}$ & $\begin{array}{l}2.65, \mathrm{~m} \\
2.11, \mathrm{~m}\end{array}$ \\
\hline 4 & $48.1, \mathrm{C}$ & & $50.7, \mathrm{C}$ & & $47.9, \mathrm{C}$ & & $48.1, \mathrm{C}$ & \\
\hline 5 & 204.3, C & & $215.7, \mathrm{C}$ & & 204.0, C & & 204.2, C & \\
\hline 6 & 126.7, CH & $5.90, \mathrm{~d}(9.8)$ & $28.4, \mathrm{CH}_{2}$ & $\begin{array}{l}1.91, \mathrm{t}(12.2) \\
1.04, \mathrm{~m}\end{array}$ & 127.2, CH & $6.06, d(10.0)$ & $127.1, \mathrm{CH}$ & $6.04, d(10.2)$ \\
\hline 7 & $154.9, \mathrm{CH}$ & $6.33, \mathrm{~d}(9.9)$ & $35.4, \mathrm{CH}_{2}$ & $\begin{array}{l}1.40, \mathrm{~m} \\
1.34, \mathrm{~m}\end{array}$ & $154.8, \mathrm{CH}$ & $7.10, \mathrm{~d}(10.0)$ & $153.8, \mathrm{CH}$ & $7.18, d(10.2)$ \\
\hline 8 & $36.5, \mathrm{C}$ & & $32.2, \mathrm{C}$ & & $42.1, \mathrm{C}$ & & $38.3, \mathrm{C}$ & \\
\hline 9 & $40.1, \mathrm{CH}$ & $2.02, \mathrm{t}(9.7)$ & $43.2, \mathrm{CH}$ & $1.75, \mathrm{t}(9.3)$ & $40.9, \mathrm{CH}$ & $2.19, \mathrm{t}(10.5)$ & $38.3, \mathrm{CH}$ & $1.93, \mathrm{t}(9.6)$ \\
\hline 10 & 28.3, $\mathrm{CH}_{2}$ & $\begin{array}{l}1.64, \mathrm{~m} \\
1.33, \mathrm{~m}\end{array}$ & $28.4, \mathrm{CH}_{2}$ & $\begin{array}{l}1.57, \mathrm{~m} \\
1.32, \mathrm{~m}\end{array}$ & $28.3, \mathrm{CH}_{2}$ & $\begin{array}{l}1.65, \mathrm{~m} \\
1.36, \mathrm{~m}\end{array}$ & $28.1, \mathrm{CH}_{2}$ & $\begin{array}{l}1.62, \mathrm{~m} \\
1.40, \mathrm{~m}\end{array}$ \\
\hline 11 & $36.5, \mathrm{CH}$ & $2.19, \mathrm{~m}$ & $36.5, \mathrm{CH}$ & $2.15, \mathrm{~m}$ & $37.7, \mathrm{CH}$ & $2.32, \mathrm{br} \mathrm{s}$ & $36.5, \mathrm{CH}$ & $2.34, \mathrm{~m}$ \\
\hline 12 & $27.0, \mathrm{CH}_{2}$ & $\begin{array}{l}1.75, \mathrm{~m} \\
1.28, \mathrm{~m}\end{array}$ & $27.0, \mathrm{CH}_{2}$ & $\begin{array}{l}1.58, \mathrm{~m} \\
1.51, \mathrm{~m}\end{array}$ & 28.3, $\mathrm{CH}_{2}$ & $\begin{array}{l}1.36, \mathrm{~m} \\
1.24, \mathrm{~m}\end{array}$ & $26.5, \mathrm{CH}_{2}$ & $\begin{array}{l}1.82, \mathrm{~m} \\
1.53, \mathrm{~m}\end{array}$ \\
\hline 13 & $26.4, \mathrm{CH}_{2}$ & $\begin{array}{l}1.52, \mathrm{~m} \\
1.49, \mathrm{~m}\end{array}$ & $25.4, \mathrm{CH}_{2}$ & $1.33, \mathrm{~m}$ & 67.3, $\mathrm{CH}$ & $4.62, d(8.5)$ & 20.6, $\mathrm{CH}_{2}$ & $\begin{array}{l}2.23, \mathrm{t}(11.5) \\
1.69, \mathrm{~m}\end{array}$ \\
\hline 14 & $44.8, \mathrm{CH}_{2}$ & $\begin{array}{l}2.16, d(16.1) \\
1.95, d(16.2)\end{array}$ & $46.5, \mathrm{CH}_{2}$ & $\begin{array}{l}2.16, d(15.9) \\
1.98, d(16.0)\end{array}$ & $46.2, \mathrm{CH}_{2}$ & $\begin{array}{l}1.64, \mathrm{~m} \\
1.36, \mathrm{~m}\end{array}$ & $76.2, \mathrm{CH}$ & $3.99, \mathrm{~m}$ \\
\hline 15 & 149.7, C & & 149.7, C & & 149.7, C & & $149.9, \mathrm{C}$ & \\
\hline 16 & 107.7, $\mathrm{CH}_{2}$ & $\begin{array}{l}4.83, \text { br s } \\
4.70, \text { br s }\end{array}$ & $106.6, \mathrm{CH}_{2}$ & $\begin{array}{l}4.83, \text { br s } \\
4.70, \text { br s }\end{array}$ & $107.1, \mathrm{CH}_{2}$ & $\begin{array}{l}4.85, \text { br s } \\
4.74, \text { br s }\end{array}$ & $111.4, \mathrm{CH}_{2}$ & $\begin{array}{l}5.27, \text { br s } \\
5.09, \text { br s }\end{array}$ \\
\hline 17 & $21.5, \mathrm{CH}_{3}$ & $1.03, \mathrm{~s}$ & 20.5, $\mathrm{CH}_{3}$ & $1.05, \mathrm{~s}$ & $22.7, \mathrm{CH}_{3}$ & $1.05, \mathrm{~s}$ & $22.1, \mathrm{CH}_{3}$ & $1.13, \mathrm{~s}$ \\
\hline $1^{\prime}$ & $174.9, \mathrm{C}$ & & $174.9, \mathrm{C}$ & & $175.2, \mathrm{C}$ & & $175.1, \mathrm{C}$ & \\
\hline $2^{\prime}$ & $111.3, \mathrm{C}$ & & $111.8, \mathrm{C}$ & & $114.8, \mathrm{C}$ & & $115.4, \mathrm{C}$ & \\
\hline $3^{\prime}$ & 159.9, C & & 159.0, C & & 160.6, C & & $160.4, \mathrm{C}$ & \\
\hline $4^{\prime}$ & $115.8, \mathrm{C}$ & & $115.6, \mathrm{C}$ & & $115.4, \mathrm{C}$ & & $115.5, \mathrm{C}$ & \\
\hline $5^{\prime}$ & 158.7, C & & 158.3, C & & $157.5, \mathrm{C}$ & & $157.8, \mathrm{C}$ & \\
\hline $6^{\prime}$ & 106.2, CH & $7.19, \mathrm{~d}(8.9)$ & $105.8, \mathrm{CH}$ & 7.17, d (8.9) & $104.9, \mathrm{CH}$ & $7.10, \mathrm{~d}(8.9)$ & $105.1, \mathrm{CH}$ & $7.12, \mathrm{~d}(8.7)$ \\
\hline $7^{\prime}$ & 130.3, CH & $8.18, \mathrm{~d}(8.9)$ & $130.1, \mathrm{CH}$ & $8.17, \mathrm{~d}(8.9)$ & $130.2, \mathrm{CH}$ & $8.33, \mathrm{~d}(8.9)$ & $130.2, \mathrm{CH}$ & $8.28, \mathrm{~d}(8.8)$ \\
\hline $1^{\prime \prime}$ & 103.7, CH & $5.71, \mathrm{~d}(7.4)$ & $103.5, \mathrm{CH}$ & $5.69, \mathrm{~d}(7.6)$ & 103.7, CH & $5.65, d(7.5)$ & 103.7, CH & $5.68, d(7.6)$ \\
\hline $2^{\prime \prime}$ & $75.4, \mathrm{CH}$ & $4.29, \mathrm{t}(7.7)$ & $75.2, \mathrm{CH}$ & $4.28, \mathrm{t}(7.7)$ & $75.4, \mathrm{CH}$ & $4.26, \mathrm{t}(7.5)$ & $75.4, \mathrm{CH}$ & $4.28, \mathrm{t}(7.7)$ \\
\hline $3^{\prime \prime}$ & $78.2, \mathrm{CH}$ & $4.36, \mathrm{~m}$ & $78.0, \mathrm{CH}$ & $4.35, \mathrm{~m}$ & $78.2, \mathrm{CH}$ & $4.32, \mathrm{~m}$ & $78.2, \mathrm{CH}$ & $4.36, \mathrm{~m}$ \\
\hline $4^{\prime \prime}$ & $71.2, \mathrm{CH}$ & $4.34, \mathrm{~m}$ & $71.1, \mathrm{CH}$ & $4.34, \mathrm{~m}$ & $71.3, \mathrm{CH}$ & $4.33, \mathrm{~m}$ & $71.3, \mathrm{CH}$ & $4.34, \mathrm{~m}$ \\
\hline $5^{\prime \prime}$ & $79.4, \mathrm{CH}$ & $4.15, \mathrm{~m}$ & $79.2, \mathrm{CH}$ & $4.13, \mathrm{~m}$ & $79.2, \mathrm{CH}$ & 4.09, m & 79.3, $\mathrm{CH}$ & $4.11, \mathrm{~m}$ \\
\hline $6^{\prime \prime}$ & 62.7, $\mathrm{CH}_{2}$ & $\begin{array}{c}4.56, d(11.8) \\
4.42, \text { dd }(11.7,4.5)\end{array}$ & $62.5, \mathrm{CH}_{2}$ & $\begin{array}{l}4.54, \text { dd }(12.0,4.1) \\
4.41, \text { dd }(12.0,4.1)\end{array}$ & $62.7, \mathrm{CH}_{2}$ & $\begin{array}{c}4.52, \mathrm{~d}(11.4) \\
4.40, \text { dd }(11.6,4.2)\end{array}$ & 62.7, $\mathrm{CH}_{2}$ & $\begin{array}{c}4.52, \mathrm{~d}(11.7) \\
4.41, \mathrm{dd}(11.7,4.3)\end{array}$ \\
\hline $\mathrm{NH}$ & & $10.82, \mathrm{~s}$ & & $10.69, \mathrm{~s}$ & & $10.68, \mathrm{~s}$ & & $10.70, \mathrm{~s}$ \\
\hline
\end{tabular}

${ }^{a 1} \mathrm{H}$ and ${ }^{13} \mathrm{C}$ assignments were based on COSY, HMBC, HSQC and TOCSY spectra, as well as in comparison with the assignments for other platensimycin and platencin glucosides reported previously.

and the $\mathrm{C}-5^{\prime}$ position cannot tolerate large group for biological activity.

Antibiotic-producing Streptomyces must have co-evolved, with their antibiotic biosynthetic machinery, strategies for self-protection from their own biologically active metabolites. Bioinformatics analysis of the genes within the ptm and ptn biosynthetic gene clusters from S. platensis MA7327 and MA7339 have previously unveiled several candidates, potentially conferring PTM and PTN self-protection via FabF/H alteration and PTM and PTN efflux. ${ }^{20}$ Although no gene encoding glucosyltransferase is identified within the cloned ptm and ptn clusters, ${ }^{20}$ it is tempting to speculate that glucosylation may represent an additional mechanism of self-protection when S. platensis overproduces PTM or PTN.

\section{CONFLICT OF INTEREST}

The authors declare no conflict of interest.

\section{ACKNOWLEDGEMENTS}

We thank Dr Sheo B Singh, Merck Research Laboratories, Rahway, NJ, for providing the S. platensis MA7339 wild-type strain. This work is supported in part by NIH grant AI079070. MJS was supported in part by NIH Predoctoral Training grant GM08505. 
1 Wang, J. et al. Platensimycin is a selective FabF inhibitor with potent antibiotic properties. Nature 441, 358-361 (2006).

2 Singh, S. B. et al. Isolation, structure, and absolute stereochemistry of platensimycin, a broad spectrum antibiotic discovered using an antisense differential sensitivity strategy. J. Am. Chem. Soc. 128, 11916-11920 (2006).

3 Wang, J. et al. Discovery of platencin, a dual FabF and FabH inhibitor with in vivo antibiotic properties. Proc. Natl Acad. Sci. USA 104, 7612-7616 (2007).

4 Jayasuriya, H. et al. Isolation and structure of platencin: a FabH and FabF dual inhibitor with potent broad-spectrum antibiotic activity. Angew. Chem. Int. Ed. Engl. 46, 4684-4688 (2007)

5 Wu, M. et al. Antidiabetic and antisteatotic effects of the selective fatty acid synthase (FAS) inhibitor platensimycin in mouse models of diabetes. Proc. Natl Acad. Sci. USA 108, 5378-5383 (2011)

6 Manallack, D. T., Crosby, I. T., Khakham, Y. \& Capuano, B. Platensimycin: a promising antimicrobial targeting fatty acid synthesis. Curr. Med. Chem. 15, 705-710 (2008).

7 Martens, E. \& Demain, A. L. Platensimycin and platencin: promising antibiotics for future application in human medicine. J. Antibiot. 64, 705-710 (2011).

8 Saleem, M., Hussain, H., Ahmed, I., van Ree, T. \& Krohn, K. Platensimycin and its relatives: a recent story in the struggle to develop new naturally derived antibiotics. Nat. Prod. Rep. 28, 1534-1579 (2011).

9 Singh, S. B., Herath, K. B., Wang, J., Tsou, N. \& Ball, R. G. Chemistry of platensimycin. Tetrahedron Lett. 48, 5429-5433 (2007).

10 Jayasuriya et al. Structure of homoplatensimide A: a potential key biosynthetic intermediate of platensimycin isolated from Streptomyces platensis. Tetrahedron Lett. 49, 3648-3651 (2008).

11 Herath, K. B. et al. Structure and semisynthesis of platensimide A, produced by Streptomyces platensis. Org. Lett. 10, 1699-1702 (2008).
12 Zhang, C. et al. Isolation, structure and fatty acid synthesis inhibitory activities of platensimycin B1-B3 from Streptomyces platensis. Chem. Commun 28, 5034-5036 (2008).

13 Singh, S. B. et al. Isolation, enzyme-bound structure, and activity of platensimycin A1 from Streptomyces platensis. Tetrahedron Lett. 50, 5182-5185 (2009).

14 Singh, S. B. et al. Isolation, enzyme-bound structure and antibacterial activity of platencin A1 from Streptomyces platensis. Bioorg. Med. Chem. Lett. 19, 4756-4759 (2009).

15 Zhang, C. et al. Isolation, structure and biological activities of platensimycin B4 from Streptomyces platensis. J. Antibiot. 62, 699-702 (2009).

16 Zhang, C. et al. Isolation, structure and biological activities of platencin A2-A4 from Streptomyces platensis. Bioorg. Med. Chem. 18, 2602-2610 (2010).

17 Zhang, C. et al. Platensimycin and platencin congeners from Streptomyces platensis. J. Nat. Prod. 74, 329-340 (2011).

18 Smanski, M. J., Peterson, R. M., Rajski, S. R. \& Shen, B. Engineered Streptomyces platensis strains that overproduce antibiotics platensimycin and platencin. Antimicrob. Agents Chemother. 53, 1299-1304 (2009).

$19 \mathrm{Yu}$, Z. et al. Engineering of Streptomyces platensis MA7339 for overproduction of platencin and congeners. Org. Lett. 12, 1744-1747 (2010).

20 Smanski, M. J. et al. Dedicated ent-kaurene and ent-atiserene synthases for platensimycin and platencin biosynthesis. Proc. Natl Acad. Sci. USA 108, 13498-13503 (2011).

21 Smanski, M. J. et al. Expression of the platencin biosynthetic gene cluster in heterologous hosts yielding new platencin congeners. J. Nat. Prod. 75, 2158-2167 (2012).

22 Chen, Y., Smanski, M. J. \& Shen, B. Improvement of secondary metabolite production in Streptomyces by manipulating pathway regulation. Appl. Microbiol. Biotechnol. 86, 19-25 (2010).

Supplementary Information accompanies the paper on The Journal of Antibiotics website (http://www.nature.com/ja) 